\title{
The Impact of Changes in Medicaid Provider Fees on Provider Participation and Enrollees' Care: a Systematic Literature Review
}

\author{
Loren Saulsberry, $P h D^{1,2}$, Veri Seo, $B A^{7}$, and Vicki Fung, $P h D^{1,3}$ \\ ${ }^{1}$ Health Policy Research Center, Mongan Institute, Massachusetts General Hospital, Boston, MA, USA; ${ }^{2}$ Department of Public Health Sciences, The \\ University of Chicago, Chicago, IL, USA; ${ }^{3}$ Department of Medicine, Harvard Medical School, Boston, MA, USA.
}

\begin{abstract}
BACKGROUND: Changing Medicaid fees is a common approach for states to address budget fluctuations, and many currently set Medicaid physician fees at levels lower than Medicare and private insurers. The Affordable Care Act included a temporary Medicaid fee bump for primary care providers (PCPs) in 2013-2014 that recently led to both an increase and then subsequent decrease in PCP fees in many states.
\end{abstract}

OBJECTIVE: To conduct a systematic literature review on the effects of changing Medicaid fees on provider participation and enrollees' access to care and service use.

METHODS: We searched PubMed/Medline and JSTOR and identified 18 studies that assessed the longitudinal impact of provider fee changes in Medicaid on the outcomes of interest. We summarized information on study design, methods, and findings.

RESULTS: Seven studies examined the impact of fee changes on provider participation in Medicaid. Of these, three studies found that fee increases were associated with positive effects on providers' likelihood of accepting Medicaid patients or on their Medicaid caseloads. Five studies that examined the impact of fee changes on Medicaid enrollees' access to care found a positive association with one or more access measure, such as having a usual source of care or appointment availability. Lastly, eight of 14 studies that examined service use found positive associations between fee changes and at least one measure of use, such as changes in the probability of enrollees having any visit, the number of visits, and shifts in the site of care toward office-based care; others largely did not find significant associations.

CONCLUSIONS: There is mixed evidence on the impact of changing Medicaid fees on provider participation and enrollees' service use; however, increasing fees appears to have more consistent positive effects on access to care. Whether these improvements in access translate into better health outcomes or downstream cost savings are critical questions.

KEY WORDS: Medicaid; health policy; access to care; utilization.

J Gen Intern Med 34(10):2200-9

DOI: $10.1007 / \mathrm{s} 11606-019-05160-\mathrm{x}$

(C) Society of General Internal Medicine 2019

Received February 5, 2019

Revised April 30, 2019

Accepted June 19, 2019

Published online August 6, 2019

\section{INTRODUCTION}

Controlling growth in Medicaid spending is a persistent challenge for states, and lowering provider fees has been a common approach for reducing Medicaid spending. ${ }^{1}$ Many states set Medicaid provider fees at levels that are lower than Medicare and private insurance payments, and low fees have been commonly cited by providers as a reason for not accepting Medicaid patients. ${ }^{2,3}$ In 2016, Medicaid paid primary care providers (PCPs) an average of $72 \%$ of Medicare fees and there is wide variation across states ranging from 38 to $126 \%$. $^{2}$ The Affordable Care Act (ACA) included a temporary Medicaid fee bump for primary care providers (PCPs) to Medicare levels in 2013-2014 to address potential shortages of PCPs for Medicaid enrollees, especially as many states adopted Medicaid expansion for low-income adults (37 states to date). As of 2018, only 17 states have continued this fee increase fully or partially, with most other states returning to lower pre-ACA fee levels.

A number of cross-sectional studies have found that in states with higher Medicaid payment rates, provider participation levels are higher, for example, as measured by their willingness to accept new Medicaid patients in their practice. ${ }^{3-8}$ Cross-sectional studies also suggest that access to care could be greater for enrollees living in higher- vs. lower-fee states, such as enrollees being more likely to report having a usual source of care and having higher rates of outpatient visits and receipt of certain preventive services. ${ }^{6,9,10}$ To the extent that higher fees increase the likelihood that enrollees receive appropriate medical care in the outpatient setting, raising fees could also improve health outcomes and reduce Medicaid spending, such as by decreasing inappropriate use of the emergency department or preventable hospitalizations. Studies that rely on cross-sectional comparisons across states with higher vs. lower fee levels, however, could be confounded by other differences, such as differences in state Medicaid coverage policies, benefit generosity, and program eligibility criteria.

We sought to systematically review the literature that examines the longitudinal impact of increasing or decreasing fees for outpatient providers, which provides stronger evidence on the potential causal effects of fee changes on providers and enrollees. We focused on three major categories of outcomes: 
provider participation, enrollee access to care, and service utilization.

\section{METHODS}

\section{Search}

We iteratively developed a search query that broadly identified studies through 2018 that examined the role of Medicaid provider fees. Our final search term was "Medicaid AND (provider* OR physician* OR doctor* OR (primary and care) OR specialist) AND (reimburs* OR pay OR payment OR fee OR charge OR fees OR charges OR payments)," which we conducted in two primary databases: PubMed/Medline and JSTOR. Our initial search of these databases identified 7081 unique titles (Fig. 1). We examined bibliographies of the studies selected for full article review, which yielded no additional articles for review through January 2019.

\section{Title and Abstract Review}

Two study team members independently screened the titles identified from the search for relevance to Medicaid fees and the following outcomes: provider participation, access to care, utilization or quality, health outcomes, and Medicaid spending. Because of the small number of articles that examined the latter two outcomes, we subsequently excluded these studies from our review after the full article review stage. At the conclusion of title review, there was a high level of agreement, with any discrepancies (60 of the 7081 titles) resolved by consensus. A total of 652 articles were selected for abstract review (Fig. 1); during this stage, two study team members reviewed the abstracts to identify empirical studies that assessed the impact of Medicaid fees on the outcomes of interest and identified 161 studies for full article review.

\section{Inclusion Criteria}

All articles selected for full article review were abstracted to determine whether they examined one or more of our outcomes of interest and matched other inclusion criteria. We excluded studies that used cross-sectional vs. longitudinal designs and those that focused on the impact of changing the payment mechanisms (e.g., fee-for-service vs. capitation or pay-for-performance) vs. changes in provider fee levels. We also excluded non-empirical studies (e.g., perspectives, commentaries) and those not published in peer-reviewed journals, including reports and working papers. We further limited our sample to studies focused on Medicaid and changes in provider payment in the outpatient setting and excluded those examining dental care, as there is greater variability across states in coverage of dental services.

We identified a total of 22 studies that examined the impact of changes in fees over time. Among these studies, we further restricted our review to studies that met criteria set by the
Cochrane Collaborative for observational studies, which we slightly modified. ${ }^{11}$ The Cochrane Collaborative recommends requiring pre-post studies to have at least two intervention and two control groups; however, we relaxed this criterion slightly to include studies that had just a single intervention and control state. For interrupted time series studies, we excluded four studies that did not have at least three pre- and three postintervention time periods but retained studies with only a single pre- or post-fee change year if their primary unit of analysis was a quarter or month and thus included three or more pre- and post-intervention time periods. ${ }^{4,12-14}$ Because the studies included in the review varied in their measurement of fee changes, outcome definitions, and study designs, we did not attempt to combine and summarize the results using a meta-analysis. Our final sample included 18 studies (Fig. 1).

\section{Content Abstraction and Synthesis}

We abstracted the following information from the studies in the review using a structured form: research question and hypotheses, study design, primary data sources, predictor variable measurement (i.e., operational definition of fees and fee changes), outcome measures, findings, implications, and limitations. We classified studies as having one of four basic study designs, which vary in their methodological approaches and ability to address potential unobserved confounding. From most to least susceptible to potential confounding, the designs included: (1) interrupted time series designs with no concurrent control group (ITS); (2) dose-response (DR) model designs, which leveraged differential changes in provider fees over time across states to identify the effects of fee changes; (3) difference-in-difference (DD) designs, which compared enrollees in states with fee changes vs. a control group without fee changes (e.g., Medicaid enrollees in other states without fee changes, or individuals in the same state with different insurance types); or (4) triple difference or difference-indifference-in-difference (DDD) designs, which leveraged both comparisons of Medicaid enrollees in states with different levels of fee changes over time and within state comparisons of Medicaid enrollees to those with different insurance types that did not face fee changes (e.g., privately insured or Medicare).

In cases where studies reported both univariate and multivariate findings, we report the multivariate findings. Where studies perform cross-sectional and longitudinal analyses, we report only the longitudinal results.

\section{RESULTS}

\section{Study Characteristics}

Table 1 describes the 18 studies included in the review. Six were published between 1980 and $1999,{ }^{15-20}$ five between 2000 and $2009,,^{9,21-24}$ and seven between 2010 and $2018 .^{25-31}$ In total, seven studies examined the effects of payment 

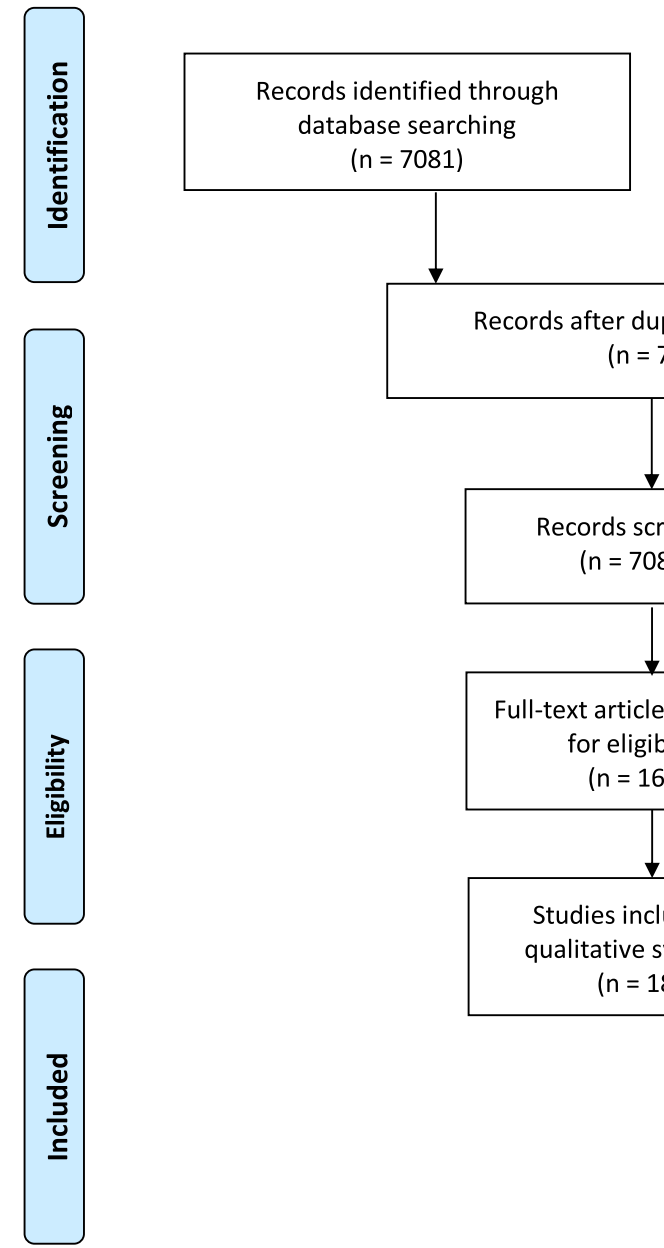

$(n=7081)$

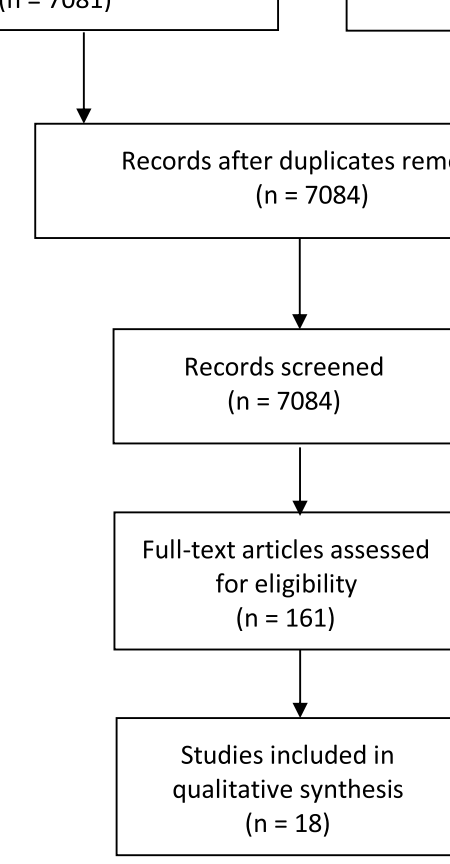

Additional records identified through other sources $(n=3)$

Figure 1 PRISMA flow diagram.

Table 1 Summary of Studies Examining the Effects of Changing Medicaid Provider Fees

\begin{tabular}{|c|c|c|c|c|c|c|c|}
\hline \multirow[b]{2}{*}{ Author(s) } & \multirow[b]{2}{*}{$\begin{array}{c}\text { Publication } \\
\text { Year }\end{array}$} & \multicolumn{2}{|r|}{ Location } & \multirow[b]{2}{*}{$\begin{array}{l}\text { Study } \\
\text { Design }\end{array}$} & \multicolumn{3}{|c|}{ Study Outcomes } \\
\hline & & National & States & & $\begin{array}{c}\text { Provider } \\
\text { Participation }\end{array}$ & Access & Service Use \\
\hline Shwartz et al. & 1981 & & MA & ITS & & & $\checkmark$ \\
\hline Cohen & 1989 & $\checkmark$ & & $\mathrm{DR}$ & & & $\checkmark$ \\
\hline Fanning and de Alteriis & 1993 & & NY & ITS & $\checkmark$ & & $\checkmark$ \\
\hline Fox and Phua & 1994 & & MD & ITS & $\checkmark$ & & $\checkmark$ \\
\hline Gruber, Adams, and Newhouse & 1997 & & TN, GA & DD & & & $\checkmark$ \\
\hline Coburn, Long, and Marquis & 1999 & & ME, MI & ITS & $\checkmark$ & & $\checkmark$ \\
\hline Baker and Royalty & 2000 & $\checkmark$ & & $\mathrm{DR}$ & $\checkmark$ & & \\
\hline Adams & 2001 & & CA, GA, MI, TN & DR & $\checkmark$ & & $\checkmark *$ \\
\hline Mitchell and Haber & 2004 & & $\begin{array}{l}\text { AK, IN, CA, CO, KS, } \\
\text { NJ, WI, AL, MI }\end{array}$ & DDD & & & $\checkmark$ \\
\hline Shen and Zuckerman & 2005 & $\checkmark$ & & DDD & & $\checkmark$ & $\checkmark *$ \\
\hline Decker & 2009 & $\checkmark$ & & DDD & & & $\checkmark$ \\
\hline White & 2012 & $\checkmark$ & & DR & & $\checkmark$ & $\checkmark$ \\
\hline Atherly and Mortensen & 2014 & $\checkmark$ & & DDD & & & $\checkmark *$ \\
\hline Polsky et al. & 2015 & & $\begin{array}{l}\text { AR, GA, IL, IA, MA, } \\
\text { MT, NJ, OR, PA, TX }\end{array}$ & $\mathrm{DD}$ & & $\checkmark$ & \\
\hline Callison and Nguyen & 2018 & $\checkmark$ & & DDD & & $\checkmark$ & $\checkmark *$ \\
\hline Candon et al. & 2018 & & $\begin{array}{l}\text { AR, GA, IL, IA, MA, } \\
\text { MT, NJ, OR, PA, TX }\end{array}$ & DR & & $\checkmark$ & \\
\hline Decker & 2018 & $\checkmark$ & & $\mathrm{DR}$ & $\checkmark$ & & \\
\hline Mulcahy, Gracner, and Finegold & 2018 & $\checkmark$ & & ITS & $\checkmark$ & & $\checkmark$ \\
\hline Total $(n=18)$ & & 9 & 9 & & 7 & 5 & 14 \\
\hline
\end{tabular}

NOTES: ITS- Interrupted Time Series. DR- Dose-response. DD- Difference-in-Difference. DDD- Triple Difference. $\boldsymbol{J}^{*}$ indicates studies that include receipt of preventive care services as a utilization measure. 
changes on provider participation in Medicaid, five on enrollee access, and fourteen on service use. All studies used quasiexperimental methods, of which five used a triple difference (DDD) design. Two studies used a difference-in-difference (DD) design, six studies used a dose-response (DR) model that examined changes in outcomes for states with larger vs. smaller fee changes over time, and five studies used an interrupted time series (ITS) design without a concurrent control group.

\section{Provider Participation}

Of the studies examining the effects of Medicaid fees on provider participation, ${ }^{17}, 18,20-22,30,31$ there were two primary measures (Table 2): changes in the likelihood of accepting any or new Medicaid enrollees ("any participation") and changes in the number of Medicaid enrollees or appointments per provider ("caseload"). Four studies examined changes among PCPs specifically. ${ }^{17,20,30,31}$ Among the five studies examining the probability of any Medicaid participation by providers, only one study found positive effects of fee increases on the probability of participation ${ }^{17}$ and one found a slightly negative effect. ${ }^{18}$ Three studies found no significant association between fee changes and participation, including two studies that examined the effects of the ACA PCP fee bump specifically. ${ }^{30,} 31$

Of the six studies that examined changes in Medicaid caseload, two found positive associations. Using a national survey of young physicians, Baker and Royalty (2000) estimated that a $10 \%$ increase in Medicaid-to-private insurance fee ratio for obstetricians was associated with a 2.5 percentage point ( $\mathrm{pp}$ ) increase in the percent of poor patients per physician panel. ${ }^{21}$ Adams (2001) estimated that a 10pp increase in the Medicaid-to-private fee ratio was associated with an increase of eight Medicaid children per physician per year using Medicaid claims data on children in four states. ${ }^{19}$ The remaining studies found no significant association.

\section{Enrollee Access to Care}

We classified measures of access to care into three primary categories (Table 3): having a usual source of care, having unmet need (e.g., reports of going without or delaying care), and appointment availability (probability of getting a new appointment and wait times until the next available appointment).

Two studies by the same research team used an audit ("secret shopper") approach to assess changes in appointment availability after the ACA PCP fee bump. Polsky et al. (2015) found a significant $8.3 \mathrm{pp}$ increase in the probability of getting an appointment for Medicaid enrollees vs. privately insured enrollees across 10 states following the implementation of the ACA fee bump (2014 vs. 2012-2013), but no changes in wait times. ${ }^{27}$ In a follow-up study, Candon et al. (2018) used a DR approach (with no comparison group of privately insured enrollees) and estimated that $\$ 10$ increases in PCP fees were associated with a significant $1.7 \mathrm{pp}$ increase in the probability for getting a new appointment for Medicaid enrollees. ${ }^{29}$
The three remaining studies used earlier data (pre-ACA fee bump) and enrollee reports from surveys; these studies also found positive effects of fee increases on at least one measure of access. ${ }^{9,} 25,{ }^{28}$ For example, Shen and Zuckerman (2005) used a DDD design and found an increase of 1.5pp in the proportion of Medicaid vs. privately insured enrollees reporting a usual source of care with a 1 unit change in the countylevel Medicaid-to-national capitation rate; however, this study did not find significant changes in the proportion of Medicaid enrollees reporting unmet need. ${ }^{9}$ Callison and Nguyen (2018) used a similar DDD design and found that a 10pp increase in the Medicaid-to-Medicare fee ratio was associated with a $1.9 \mathrm{pp}$ increase in the proportion of Medicaid vs. low-income privately insured enrollees having a usual source of care, but not with other measures of unmet need, including delaying use of medical care or prescription drugs. ${ }^{28}$

\section{Enrollee Service Use}

We classified service use outcomes into four main subcategories (Table 4): (1) any use (e.g., at least one office visit per year); (2) service volume (e.g., total number of visits or procedures or number of visits or procedures per enrollee or provider); (3) use by site of care (e.g., office vs. emergency department); and (4) use of preventive care as a quality process measure (e.g., receipt of mammogram).

Of the seven studies that examined whether fee changes affect the probability of having any service use (e.g., outpatient visits), four studies found a positive association, , 16, 23, 24 and three studies using weaker study designs (DR and ITS) did not find significant associations. ${ }^{17,20,25}$ Two of eight studies that examined the impact of fee changes on service volume found positive associations, ${ }^{24,} 28$ and six found no significant association. $^{15,18,20,23,25,31}$

Three of seven studies examining the association between fee changes and shifts in site of care for Medicaid enrollees found increases in visit rates in outpatient office settings and decreases in visits rates in more expensive sites of care, such as emergency or hospital outpatient departments. ${ }^{18,19,24}$ In contrast, Callison and Nguyen (2018) found significant increases in utilization across all sites of care (ED, hospital outpatient departments, and officebased visits) associated with increases outpatient Medicaid-toMedicare fee ratios between 2008 and 2012. ${ }^{28}$ The three remaining papers found no significant associations across any site of care. $^{9,20,25}$

Three of the four studies that examined changes in receipt of preventive care used survey data and a DDD study design; these studies did not find a significant effect of changes in Medicaid fees on the likelihood of receiving preventive services. Both Atherly and Mortensen (2014) and Callison and Nguyen (2018) used the Medical Expenditure Panel Survey to examine changes in receipt of blood pressure and cholesterol testing, cancer screenings, and flu vaccinations. ${ }^{26,28}$ Shen and Zuckerman (2005) used three waves of the National Survey of America's Families to examine the probability of receiving a 
Table 2 Studies Examining Medicaid Fee Changes and Provider Participation

\begin{tabular}{|c|c|c|c|c|c|c|}
\hline Study & $\begin{array}{l}\text { Primary Data } \\
\text { Source \& Sample }\end{array}$ & Year(s) & $\begin{array}{l}\text { Study Design \& } \\
\text { Predictor Measure }\end{array}$ & Fee Change & Measure of Outcome & Findings \\
\hline \multirow[t]{2}{*}{$\begin{array}{l}\text { Fanning and } \\
\text { de Alteriis } \\
1993\end{array}$} & \multirow[t]{2}{*}{$\begin{array}{l}\text { Medicaid claims } \\
\text { data on all } \\
\text { physicians in NY }\end{array}$} & \multirow[t]{2}{*}{$\begin{array}{l}1982- \\
1986\end{array}$} & \multirow[t]{2}{*}{$\begin{array}{l}\text { ITS based on increases } \\
\text { in Medicaid fees for } \\
\text { primary care services }\end{array}$} & \multirow[t]{2}{*}{$+30 \%$ in 1985} & $\begin{array}{l}\text { Any participation: Monthly } \\
\text { trend in \# of physicians seeing } \\
\text { any Medicaid patients: } \\
\text { PCPs }\end{array}$ & $\begin{array}{l}\text { Change in trend: } \\
-0.009 \text { PCPs per month } \\
\text { (directionally inconsistent) }\end{array}$ \\
\hline & & & & & Non-PCPs & NS \\
\hline $\begin{array}{l}\text { Fox and } \\
\text { Phua } 1994\end{array}$ & $\begin{array}{l}\text { Medicaid claims } \\
\text { data on births in } \\
\text { MD }\end{array}$ & $\begin{array}{l}1985- \\
1988\end{array}$ & $\begin{array}{l}\text { ITS based on increases } \\
\text { in Medicaid fees for } \\
\text { births }\end{array}$ & $\begin{array}{l}\$ 265 \text { to } \$ 550 \text { in } \\
1986 \text { then to } \\
\$ 795 \text { in } 1987 \\
\text { (Medicaid to } \\
\text { private levels) }\end{array}$ & $\begin{array}{l}\text { Any participation: \# of } \\
\text { providers with any Medicaid } \\
\text { births per county per quarter } \\
\text { Caseload: \# of Medicaid births } \\
\text { per provider per year }\end{array}$ & +1.9 providers/quarter \\
\hline $\begin{array}{l}\text { Coburn, } \\
\text { Long, and } \\
\text { Marquis } \\
1999\end{array}$ & $\begin{array}{l}\text { Medicaid claims } \\
\text { data on women and } \\
\text { children in ME, MI }\end{array}$ & $\begin{array}{l}1987- \\
1992 \\
\text { ME, } \\
1989- \\
1992 \text { MI }\end{array}$ & $\begin{array}{l}\text { ITS based on increases } \\
\text { and decreases in } \\
\text { Medicaid:charges } \\
\text { (private proxy) ratio }\end{array}$ & $\begin{array}{l}\text { Varied changes } \\
\text { across years } \\
\text { ranging from - } \\
20 \% \text { to }+71.5 \% \\
\text { over } 1987-1992\end{array}$ & $\begin{array}{l}\text { Any participation: \# of PCPs } \\
\text { and OB/GYNs with any } \\
\text { Medicaid visits per month } \\
\text { Caseload: \# of physicians with } \\
\text { at least } 15 \text { Medicaid } \\
\text { visits per month }\end{array}$ & $\begin{array}{l}\text { Largely NS and not } \\
\text { directionally consistent } \\
\text { Largely NS and not } \\
\text { directionally consistent }\end{array}$ \\
\hline $\begin{array}{l}\text { Baker and } \\
\text { Royalty } \\
2000\end{array}$ & $\begin{array}{l}\text { Survey of young } \\
\text { physicians } \\
\text { providing } \\
\text { obstetrical care, } \\
\text { nationally } \\
\text { representative }\end{array}$ & $\begin{array}{l}1987, \\
1991\end{array}$ & $\begin{array}{l}\text { DR based on state } \\
\text { variation in } \\
\text { Medicaid:private fee } \\
\text { ratio for obstetrical } \\
\text { care }\end{array}$ & $\begin{array}{l}\text { Increase in } \\
1980 \mathrm{~s}, \\
\text { magnitude not } \\
\text { stated }\end{array}$ & $\begin{array}{l}\text { Caseload: } \\
\% \text { of poor patients per private } \\
\text { physician } \\
\% \text { of poor patients per public } \\
\text { physician } \\
\% \text { of poor patients per all } \\
\text { physicians }\end{array}$ & $\begin{array}{l}+10 \% \text { fee } \rightarrow+3.4 \% \\
+10 \% \text { fee } \rightarrow-3.0 \% \\
+10 \% \text { fee } \rightarrow+2.5 \%\end{array}$ \\
\hline Adams 2001 & $\begin{array}{l}\text { Medicaid claims } \\
\text { data on children } \\
<21 \text { y.o. in CA, } \\
\text { GA, MI, TN }\end{array}$ & $\begin{array}{l}1989, \\
1992\end{array}$ & $\begin{array}{l}\text { DR based on state } \\
\text { variation in } \\
\text { Medicaid:private fee } \\
\text { ratio overall and for } \\
\text { preventive services }\end{array}$ & $\begin{array}{l}\text { Varied changes } \\
\text { ranging }-5 \mathrm{pp} \text { to } \\
+8 \mathrm{pp} \text { in } 1989- \\
1992\end{array}$ & $\begin{array}{l}\text { Caseload: \# of Medicaid } \\
\text { children per physician per year }\end{array}$ & $\begin{array}{l}+10 \% \text { ratio } \rightarrow+8 \text { Medicaid } \\
\text { children per physician per } \\
\text { year }\end{array}$ \\
\hline $\begin{array}{l}\text { Decker } \\
2018\end{array}$ & $\begin{array}{l}\text { National } \\
\text { Electronic Health } \\
\text { Records Survey; } \\
\text { included PCPs } \\
\text { (general/ family } \\
\text { practice, internal } \\
\text { medicine, } \\
\text { pediatrics), } \\
\text { nationally } \\
\text { representative }\end{array}$ & $\begin{array}{l}2011 \\
2013- \\
2015\end{array}$ & $\begin{array}{l}\text { DR based on state } \\
\text { variation in } \\
\text { Medicaid:Medicare fee } \\
\text { ratio }\end{array}$ & $\begin{array}{l}\text { Varied changes } \\
\text { in fee bumps } \\
\text { from }>35 \mathrm{pp}, \\
25-34 \mathrm{pp},<25 \\
\text { pp }\end{array}$ & $\begin{array}{l}\text { Any participation: Accepts new } \\
\text { Medicaid patients } \\
>1 \% \text { of patients on Medicaid } \\
\text { Caseload: } \% \text { of patients on } \\
\text { Medicaid if accepts new } \\
\text { Medicaid patients } \\
\% \text { of patients on Medicaid if } \\
>1 \% \text { of patients on Medicaid }\end{array}$ & $\begin{array}{l}\text { NS } \\
\text { NS } \\
\text { NS }\end{array}$ \\
\hline $\begin{array}{l}\text { Mulcahy, } \\
\text { Gracner, } \\
\text { and } \\
\text { Finegold } \\
2018\end{array}$ & $\begin{array}{l}\text { IMS Health } \\
\text { medical claims and } \\
\text { encounter data; } \\
\text { includes PCPs, all } \\
\text { states except AK } \\
\text { and HI }\end{array}$ & $\begin{array}{l}2012- \\
2015\end{array}$ & $\begin{array}{l}\text { ITS based on state- } \\
\text { level change in } \\
\text { Medicaid:Medicare fee } \\
\text { ratios for primary care } \\
\text { services }\end{array}$ & $\begin{array}{l}\text { Varied changes } \\
\text { in fee bumps, } \\
\text { magnitude not } \\
\text { stated }\end{array}$ & $\begin{array}{l}\text { Any participation: Monthly } \\
\text { visits with any Medicaid } \\
\text { patient } \\
\text { Monthly visits with }>5 \\
\text { Medicaid patients } \\
\text { Caseload: Medicaid share of } \\
\text { total patients each month }\end{array}$ & NS \\
\hline
\end{tabular}

Note: ITS=Interrupted time series; DR=Dose-response; DD=Difference-in-difference; DDD=Difference-in-difference-in-difference (triple difference); $\mathrm{PCP}=$ primary care physician.

clinical breast examination, pap smear, or making at least one well-child visit in the last 12 months. ${ }^{9}$ In contrast, Adams (2001) used Medicaid claims data for children in four states in 1989 and 1992 with a DR study design, and found a positive association between Medicaid fees and the likelihood that physicians provided any preventive care services to children during the year; the magnitude was not stated. ${ }^{22}$

\section{DISCUSSION}

Our systematic review of the literature on the impact of Medicaid fees changes yielded a number of findings. First, our review suggests that the evidence that increasing Medicaid fees leads to increases in provider participation in the program is weak. Nevertheless, there was consistent evidence that fee increases were associated with improvements in certain measures of enrollee access to care, such as having a usual source of care or appointment availability. Although many studies have investigated changes in outpatient visits associated with fee changes, the evidence is largely mixed, and it is difficult to make generalizable conclusions with respect to the effect of fee changes on utilization. There was also little evidence that increasing primary care fees was associated with increases in receipt of preventive care. 
Table 3 Studies Examining Medicaid Fee Changes and Enrollee Access to Care

\begin{tabular}{|c|c|c|c|c|c|c|}
\hline Study & $\begin{array}{l}\text { Data Source \& } \\
\text { Sample }\end{array}$ & Year(s) & $\begin{array}{l}\text { Study Design \& } \\
\text { Predictor Measure }\end{array}$ & Fee Change & Measure of Outcome & Findings \\
\hline \multirow{4}{*}{$\begin{array}{l}\text { Shen and } \\
\text { Zuckerman } \\
2005\end{array}$} & \multirow{4}{*}{$\begin{array}{l}\text { Surveys of } \\
\text { Medicaid adults } \\
\text { and children and } \\
\text { county capitation } \\
\text { rates, nationally } \\
\text { representative }\end{array}$} & \multirow{4}{*}{$\begin{array}{l}1997 \\
1999 \\
2002\end{array}$} & \multirow{4}{*}{$\begin{array}{l}\text { DDD comparing } \\
\text { Medicaid vs. privately } \\
\text { insured (control) } \\
\text { combined with DR } \\
\text { based on county-level } \\
\text { Medicaid:national } \\
\text { capitation rate }\end{array}$} & \multirow{4}{*}{$\begin{array}{l}\text { Variation across } \\
\text { counties in } \\
\text { Medicaid: } \\
\text { national } \\
\text { capitation rates }\end{array}$} & $\begin{array}{l}\text { Usual source of care: Have } \\
\text { usual source of care }\end{array}$ & +1 unit $\rightarrow+1.5 \mathrm{pp}$ \\
\hline & & & & & \multirow{3}{*}{$\begin{array}{l}\text { Same provider at usual source of } \\
\text { care } \\
\text { Unmet need: Avoiding or } \\
\text { delaying medical care, } \\
\text { prescription drugs }\end{array}$} & \multirow{3}{*}{$\begin{array}{l}\text { NS } \\
\text { NS }\end{array}$} \\
\hline & & & & & & \\
\hline & & & & & & \\
\hline White 2012 & $\begin{array}{l}\text { National Health } \\
\text { Interview Survey; } \\
\text { included children, } \\
\text { nationally } \\
\text { representative }\end{array}$ & $\begin{array}{l}1997- \\
2008\end{array}$ & $\begin{array}{l}\text { DR based on state } \\
\text { variation in } \\
\text { Medicaid:Medicare fee } \\
\text { ratio }\end{array}$ & $+15 \%$ in 1997 & $\begin{array}{l}\text { Unmet need: Report having } \\
\text { non-cost related access problems }\end{array}$ & $-2 \%$ \\
\hline $\begin{array}{l}\text { Polsky et al } \\
2015\end{array}$ & $\begin{array}{l}\text { Audit study: } \\
\text { phone calls to } \\
\text { primary care } \\
\text { offices as } \\
\text { hypothetical } \\
\text { patients, } 10 \text { states }\end{array}$ & $\begin{array}{l}2012- \\
2013 \text { vs. } \\
2014\end{array}$ & $\begin{array}{l}\text { DD comparing } \\
\text { Medicaid vs. privately } \\
\text { insured (control) pre- } \\
\text { vs. post- PCP payment } \\
\text { increases }\end{array}$ & $\begin{array}{l}\text { Varied increases } \\
\text { ranging }+7 \% \text { to } \\
+109 \% \text { in } 2013- \\
2014 ; \text { mean of } \\
+57 \%\end{array}$ & $\begin{array}{l}\text { Appointment availability: } \\
\text { Probability of getting an } \\
\text { appointment for new patient } \\
\text { \# of days until next appointment } \\
\text { for new patient }\end{array}$ & $\begin{array}{l}+8.3 p p \text { overall; larger } \\
\text { increases in states with } \\
\text { larger fee increases } \\
\text { NS }\end{array}$ \\
\hline \multirow{6}{*}{$\begin{array}{l}\text { Callison and } \\
\text { Nguyen } \\
2018\end{array}$} & \multirow{6}{*}{$\begin{array}{l}\text { Medical } \\
\text { Expenditure } \\
\text { Panel Survey; } \\
\text { included adult } \\
\text { respondents with } \\
\text { Medicaid or private } \\
\text { insurance, } \\
\text { nationally } \\
\text { representative }\end{array}$} & \multirow{6}{*}{$\begin{array}{l}2008 \\
2012\end{array}$} & \multirow{6}{*}{$\begin{array}{l}\text { DDD comparing } \\
\text { Medicaid vs. low- } \\
\text { income privately } \\
\text { insured (control) } \\
\text { combined with DR } \\
\text { model based on state- } \\
\text { level changes in } \\
\text { Medicaid:Medicare fee } \\
\text { ratio }\end{array}$} & \multirow{6}{*}{$\begin{array}{l}\text { Varied changes } \\
\text { (mostly } \\
\text { decreases), } \\
\text { magnitude not } \\
\text { stated }\end{array}$} & $\begin{array}{l}\text { Usual source of care: Have } \\
\text { usual source of care }\end{array}$ & $+10 \mathrm{pp}$ in ratio $\rightarrow+1.9 \mathrm{pp}$ \\
\hline & & & & & $\begin{array}{l}\text { Unmet need: Unable to access } \\
\text { medical care }\end{array}$ & NS \\
\hline & & & & & Unable to access medication & NS \\
\hline & & & & & Delayed medical care & NS \\
\hline & & & & & Delayed medication fill & NS \\
\hline & & & & & Delayed dental care & NS \\
\hline $\begin{array}{l}\text { Candon et al } \\
2018\end{array}$ & $\begin{array}{l}\text { Audit study: Same } \\
\text { as Polsky et al. } \\
2015\end{array}$ & $\begin{array}{l}2012 \text { vs. } \\
2014 \\
2014 \text { vs. } \\
2016\end{array}$ & $\begin{array}{l}\text { DR based on state } \\
\text { variation in Medicaid } \\
\text { fees }\end{array}$ & $\begin{array}{l}\text { Varied increases } \\
(2012-2014) \text { and } \\
\text { decreases (2014- } \\
2016)\end{array}$ & $\begin{array}{l}\text { Appointment availability: } \\
\text { Probability of getting an } \\
\text { appointment for new patient }\end{array}$ & $+\$ 10$ change $\rightarrow+1.7 \mathrm{pp}$ \\
\hline
\end{tabular}

NOTES: ITS=Interrupted time series; DR=Dose-response; DD=Difference-in-difference; DDD=Difference-in-difference-in-difference

The lack of strong evidence that increasing provider fees influences provider participation in the program is concerning given that this is the underlying mechanism through which potential improvements in care access and outcomes in Medicaid are posited to be achieved. It is notable that the only study to find an impact of fee increases on extensive participation, or the probability that more providers accept Medicaid enrollees, was in the context of a single state (Maryland) that raised their fees for obstetrical care to the level of private insurers. ${ }^{18}$ This is consistent with the economic model developed by Sloan et al. (1978) that suggests that when providers have a choice of accepting patients from multiple markets (e.g., private insurance and Medicaid), they prefer patients from market from which expected revenues are greater. ${ }^{32}$ Thus, the magnitude of Medicaid fee changes relative to other local payers including Medicare and private insurers is likely to moderate the impact of Medicaid fee changes. A number of studies measured changes in provider fees by indexing Medicaid fees relative to private insurance or Medicare fees, but most did not examine variation in the effects of fee changes that occurred at the lower vs. higher end of the index.

In contrast, two studies that investigated the impact of the ACA PCP fee bump, which raised Medicaid fees to Medicare levels, found no effect on participation. The temporary nature of the fee increase, which was federally funded for only two years (2013-2014), could have reduced providers' willingness to accept new Medicaid patients, especially if there were administrative hurdles or burdens associated with entering the program. Reports also note operational issues in many states with implementing the payment bump, including delays in notifying or reimbursing providers, and lack of provider awareness of the program, which could have further discouraged participation. ${ }^{33,34}$

A research team that used a secret shopper approach to assess the effect of the ACA PCP fee bump on appointment availability for Medicaid enrollees found increases in the probability of getting a new appointment, but not appointment wait times, for Medicaid enrollees. Polsky et al. focused on physicians in 10 states that were already accepting Medicaid enrollees, so increases in appointment availability reflect increases in physician participation on the intensive margin. This contrasts with findings from Decker (2018), who used a nationally representative survey to examine changes in both the extensive and intensive participation of providers before vs. after the ACA bump and found no changes. One possible explanation for these seemingly divergent findings is that 
Table 4 Studies Examining Medicaid Fee Changes and Service Use

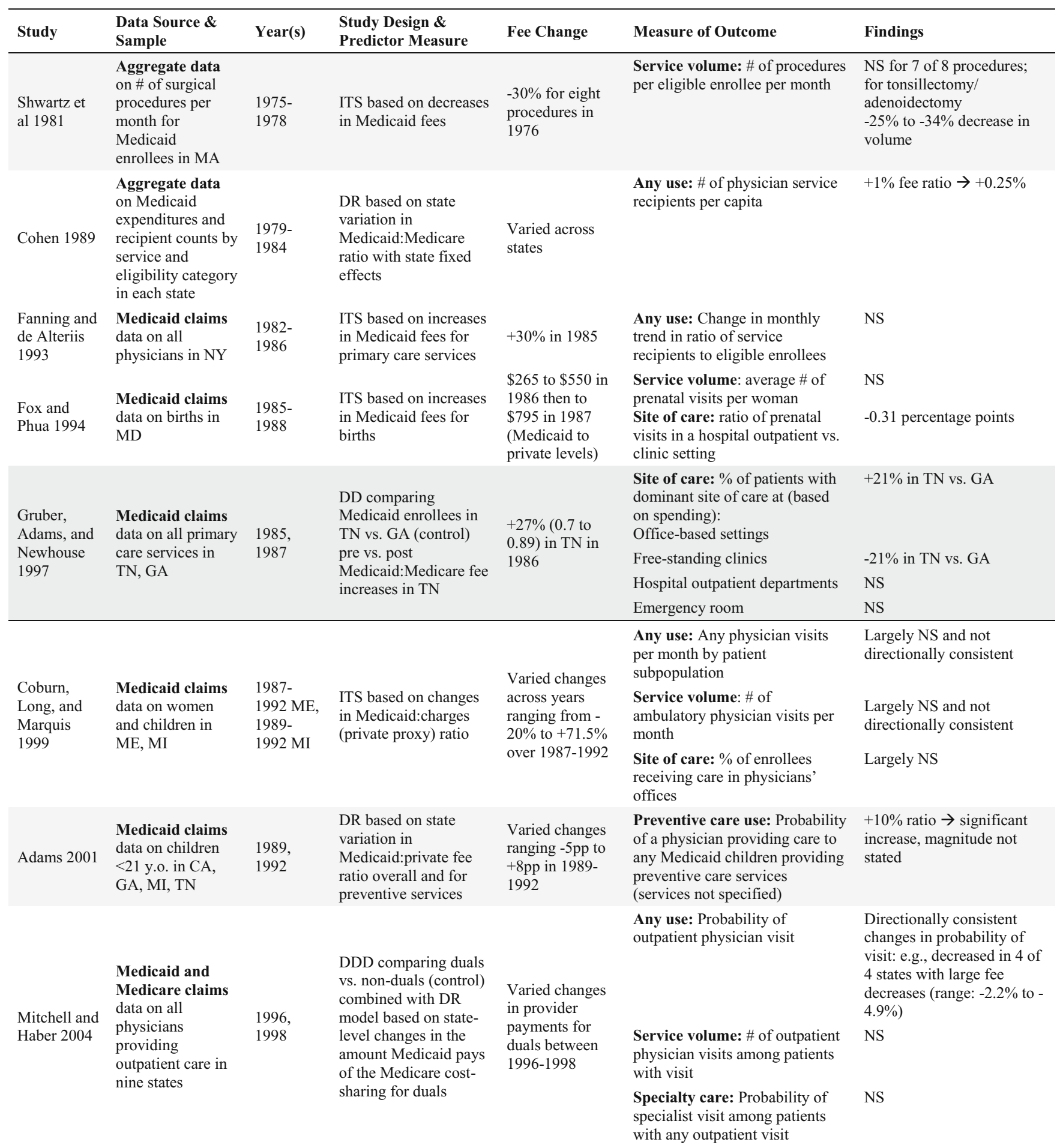

Medicaid physicians increased their time to see patients (and therefore could offer more appointments) with the fee bump but did not change the overall composition of their patient panels. Growth in the workforce of nurse practitioners and physician's assistants could also help increase primary care appointment availability. ${ }^{35}$ Importantly, most studies examining provider participation focused on physician participation and not other provider types.

Similarly, despite the weak evidence linking Medicaid fees with provider participation, two studies found positive effects of Medicaid fee increases on having a usual source of care. Having a usual source of care has been associated with 
characteristics including local demand for services relative to the supply of providers, which could moderate the effects of fee changes on outcomes for Medicaid enrollees.

There was a small body of evidence on the impact of fee changes on use of preventive services. The findings from these studies suggest that fee increases, on their own, could be insufficient to increase use of high-value or cost-effective preventive care, especially in the context of traditional fee-for-service (FFS) reimbursement. A number of states are currently implementing Accountable Care Organizations as a means of reforming payment and care delivery within their Medicaid programs, which could provide greater incentives for quality improvement.

Importantly, the majority of Medicaid enrollees nationally are currently enrolled in comprehensive managed care plans, which could also have greater incentives for increasing use of high-value preventive services $\left(65 \%\right.$ in 2015) ${ }^{39}$ The fee changes that are the focus of this review primarily applied to Medicaid FFS payments, which now represent a minority of enrollees but the majority of Medicaid spending because FFS enrollees are more likely to be elderly and disabled. ${ }^{40}$ Moreover, many states require that rates within Medicaid managed care match FFS rate changes, at least in part. ${ }^{41}$ We did not find evidence, however, on whether FFS fee changes had spill-over effects on Medicaid managed care enrollees. This could be, in part, due to the difficulty obtaining reliable and comprehensive encounter data for Medicaid managed care enrollees. ${ }^{42,} 43$

This review highlights the broader challenge of studying the Medicaid program and the critical need for timely and consistent data. There is about a 4-year lag to availability of Medicaid Analytic Extract (MAX) data from the Centers for Medicare and Medicaid Services (CMS) for many states, in part due to the effort needed to standardize and validate data across states. CMS efforts to improve the quality, comparability, and timeliness of Medicaid data through the Transformed Medicaid Statistical Infrastructure System (T-MSIS) could serve as an important building block for improving the Medicaid research infrastructure. Improving the ability to link these data with additional information, such as vital statistics, local and national disease registries, and electronic health records would improve our ability to study the impact of Medicaid policy on health outcomes, for which there is currently limited evidence.

\section{Limitations}

Our review is subject to limitations. We did not include a start date for our review, which spans nearly four decades. During this time the Medicaid program has undergone numerous changes, including large increases in the number of beneficiaries enrolled in managed care plans and expansions in the populations eligible for Medicaid; these changes could impact the effects of fee changes on provider participation and beneficiary access to care.

\section{Conclusion}

In summary, this review did not find strong evidence that increasing Medicaid provider fees positively affects provider participation in the program, although some measures of enrollee access improved with higher fees. Fee changes should be accompanied with careful monitoring of changes in access to care and downstream outcomes. Attention is also needed to identify and implement other strategies that could have more consistent effects on care utilization and quality.

Corresponding Author: Loren Saulsberry, PhD; Department of Public Health Sciences The University of Chicago, Chicago, IL, USA (e-mail: lsaulsberry@uchicago.edu).

Funding Information The Agency for Healthcare Research and Quality (RO1HSO24725) and National Institute on Minority Health and Health Disparities (R01MD010456) provided funding for this study.

\section{Compliance with Ethical Standards:}

Conflict of Interest: The authors declare that they do not have a conflict of interest.

Disclaimer: The funders had no role in the design, conduct, or reporting of this study.

\section{REFERENCES}

1. The Medicaid and CHIP Payment Access Commission (MACPAC). Chapter 2: Addressing growth in Medicaid spending: state options. Report to Congress on Medicaid and CHIP 2016. Available at: https:// www.macpac.gov/publication/addressing-growth-in-medicaid-spending-state-options/. Accessed 22 May 2019.

2. Kaiser Family Foundation. Medicaid-to-Medicare fee index. 2016. Available at: https://www.kff.org/medicaid/state-indicator/medicaid-tomedicare-fee-index $/$ ?currentTimeframe $=0$ \& sortModel $=\% 7 \mathrm{~B} \% 22$ colId\%22:\%22Location\%22,\%22sort\%22:\%22asc\%22\%7D. Accessed 22 May 2019.

3. Berman S, Dolins J, Tang SF, Yudkowsky B. Factors that influence the willingness of private primary care pediatricians to accept more Medicaid patients. Pediatrics. 2002;110(2 Pt 1):239-248.

4. Zuckerman S, McFeeters J, Cunningham P, Nichols L. Changes in medicaid physician fees, 1998-2003: implications for physician participation. Health Aff (Millwood). 2004;Suppl Web Exclusives:W4374-384.

5. Decker SL. In 2011 nearly one-third of physicians said they would not accept new Medicaid patients, but rising fees may help. Health Aff (Millwood) 2012;31(8):1673-1679.

6. Cohen JW, Cunningham PJ. Medicaid physician fee levels and children's access to care. Health Aff (Millwood). 1995;14(1):255-262.

7. Perloff JD, Kletke P, Fossett JW. Which physicians limit their Medicaid participation, and why. Health Serv Res 1995;30(1):7-26.

8. Perloff JD, Kletke PR, Neckerman KM. Recent trends in pediatrician participation in Medicaid. Med Care 1986;24(8):749-760.

9. Shen YC, Zuckerman S. The effect of Medicaid payment generosity on access and use among beneficiaries. Health Serv Res 2005;40(3):723744.

10. Yoo BK, Berry A, Kasajima M, Szilagyi PG. Association between Medicaid reimbursement and child influenza vaccination rates. Pediatrics. 2010;126(5):e998-1010.

11. Ryan R, Hill S, Prictor M, McKenzie J. Cochrane Consumers and Communication Review Group. Study Quality Guide. May 2013. Available at: http://cccrg.cochrane.org/author-resources. Accessed 22 May 2019.

12. Cossman JS, Ritchie JB, Cosby AG. Medicaid reimbursement and access to physicians: does lower reimbursement mean less access to care? J Miss State Med Assoc 2006;47(11):323-336.

13. McKay NL, Dorner FH. Physician response to a change in Medicaid fees. Health Serv Manag Res 1999;12(2):69-78.

14. Tang SS, Hudak ML, Cooley DM, Shenkin BN, Racine AD. Increased Medicaid payment and participation by office-based primary care 
pediatricians. Pediatrics. 2018;141(1):1-9. Available at: https://doi.org/ 10.1542/peds.2017-2570. Accessed May 22, 2019.

15. Shwartz M, Martin SG, Cooper DD, Ljung GM, Whalen BJ, Blackburn $\mathbf{J}$. The effect of a thirty per cent reduction in physician fees on Medicaid surgery rates in Massachusetts. Am J Public Health 1981;71(4):370-375.

16. Cohen JW. Medicaid policy and the substitution of hospital outpatient care for physician care. Health Serv Res 1989;24(1):33-66.

17. Fanning $\mathbf{T}$, de Alteriis $\mathbf{M}$. The limits of marginal economic incentives in the Medicaid program: concerns and cautions. J Health Polit Policy Law 1993; 18(1):27-42.

18. Fox MH, Phua KL. Using Medicaid claims data to evaluate a large physician fee increase. Health Serv Res 1994;29(3):315-340.

19. Gruber J, Adams K, Newhouse JP. Physician Fee Policy and Medicaid Program Costs. J Hum Resour 1997;32(4):611-634.

20. Coburn AF, Long SH, Marquis MS. Effects of changing Medicaid fees on physician participation and enrollee access. Inquiry. 1999;36(3):265-279.

21. Baker LC, Royalty AB. Medicaid Policy, Physician Behavior, and Health Care for the Low-Income Population. J Hum Resour 2000;35(3):480-502.

22. Adams EK. Factors affecting physician provision of preventive care to Medicaid children. Health Care Financ Rev 2001;22(4):9-26.

23. Mitchell JB, Haber SG. State Payment Limitations on Medicare CostSharing: Impact on Dually Eligible Beneficiaries. Inquiry. 2004;41(4):391-400.

24. Decker SL. Changes in Medicaid physician fees and patterns of ambulatory care. Inquiry. 2009;46(3):291-304.

25. White C. A comparison of two approaches to increasing access to care: expanding coverage versus increasing physician fees. Health Serv Res 2012;47(3 Pt 1):963-983.

26. Atherly A, Mortensen $\mathbf{K}$. Medicaid primary care physician fees and the use of preventive services among Medicaid enrollees. Health Serv Res 2014;49(4):1306-1328

27. Polsky D, Richards M, Basseyn S, et al. Appointment availability after increases in Medicaid payments for primary care. N Engl J Med 2015;372(6):537-545

28. Callison K, Nguyen BT. The Effect of Medicaid Physician Fee Increases on Health Care Access, Utilization, and Expenditures. Health Serv Res 2018;53(2):690-710.

29. Candon M, Zuckerman S, Wissoker D, et al. Declining Medicaid Fees and Primary Care Appointment Availability for New Medicaid Patients. JAMA Intern Med 2018;178(1):145-146.

30. Decker SL. No Association Found Between The Medicaid Primary Care Fee Bump and Physician-Reported Participation in Medicaid. Health Af (Millwood). 2018;37(7):1092-1098. https://doi.org/10.1377/hlthaff. 2018.0078. Accessed May 22, 2019.

31. Mulcahy AW, Gracner T, Finegold K. Associations Between the Patient Protection and Affordable Care Act Medicaid Primary Care Payment Increase and Physician Participation in Medicaid. JAMA Intern Med 2018;178(8):1042-1048. Available at: https://doi.org/10.1001/jamainternmed.2018.2610. Accessed May 22, 2019.

32. Sloan F, Mitchell J, Cromwell J. Physician participation in state Medicaid programs. J Hum Resour 1978;13 Suppl:211-245.

33. Medicaid and CHIP Payment and Access Commission. An Update on the Medicaid Primary Care Payment Increase. Washington, DC Mar 2015. Available at: https://www.macpac.gov/publication/an- update-on-the-medicaid-primary-care-payment-increase-3/. Accessed May 22, 2019.

34. Kaiser Family Foundation and The Commonwealth Fund. Experiences and Attitudes of Primary Care Providers Under the First Year of ACA Coverage Expansion: Findings from the Kaiser Family Foundation/ Commonwealth Fund 2015 National Survey of Primary Care Providers. Issue Brief. June 2015. Available at: https://www.commonwealthfund. org/sites/default/files/documents/_media files_publications issue brief_2015_jun_1823_kaiser_commonwealth_primary_care_survey_ib. pdf. Accessed May 22, 2019.

35. Xue Y, Smith JA, Spetz J. Primary Care Nurse Practitioners and Physicians in Low-Income and Rural Areas, 2010-2016. JAMA. 2019;321(1):102-105. Available at: https://doi.org/10.1001/jama.2018. 17944. Accessed May 22, 2019.

36. DeVoe JE, Tillotson CJ, Wallace LS. Usual Source of Care as a Health Insurance Substitute for U.S. Adults With Diabetes? Diabetes Care 2009;32(6):983-989. Available at: https://doi.org/10.2337/dc09-0025. Accessed May 22, 2019.

37. Blewett LA, Johnson PJ, Lee B, Scal PB. When a usual source of care and usual provider matter: adult prevention and screening services. J Gen Intern Med 2008;23(9):1354-60.

38. Green CA, Johnson KM, Yarborough BJ. Seeking, delaying, and avoiding routine health care services: patient perspectives. Am J Health Promot 2013;28(5):286-93.

39. The Medicaid and CHIP Payment Access Commission (MACPAC). Exhibit 29: Percentage of Medicaid Enrollees in Managed Care by state, July 1 , 2015. MACStats: Medicaid and CHIP data book 2017. Available at: https://www.macpac.gov/wp-content/uploads/2015/12/MACStatsMedicaid-CHIP-Data-Book-December-2017.pdf. Accessed 22 May 2019.

40. The Medicaid and CHIP Payment Access Commission (MACPAC). Exhibit 17: Total Medicaid benefit spending by state and category, FY2016 (millions). MACStats: Medicaid and CHIP data book 2017. Available at: https://www.macpac.gov/wp-content/uploads/2015/12/MACStatsMedicaid-CHIP-Data-Book-December-2017.pdf. Accessed 22 May 2019.

41. Gifford K, Ellis E, Edwards BC, et al. Medicaid Moving Ahead in Uncertain Times: Results from a 50-State Medicaid Budget Survey for State Fiscal Years 2017 and 2018. Kaiser Family Foundation. 2017. Available at: https://www. kff.org/report-section/medicaid-moving-ahead-in-uncertain-times-providerrates-and-taxes/. Accessed 22 May 2019.

42. Byrd VLH, Dodd HA. Assessing the Usability of Encounter Data for Enrollees in Comprehensive Managed Care Across MAX 2007-2009. Centers for Medicare \& Medicaid Services; Dec 2012. Brief 15. Available at: https://www.cms.gov/Research-Statistics-Data-and-Systems/Computer-Data-and-Systems/MedicaidDataSourcesGenInfo/Downloads / MAX_IB_15_AssessingUsability.pdf. Accessed 22 May 2019.

43. Nysenbaum JB, Bouchery E, Malsberger R. Availability and usability of behavioral health organization encounter data in MAX 2009. Medicare Medicaid Res Rev 2014;4(2).

Publisher's Note Springer Nature remains neutral with regard to jurisdictional claims in published maps and institutional affiliations. 